\title{
Emerging role of testosterone in pancreatic $\beta$ cell function and insulin secretion
}

\author{
Weiwei Xu, Jamie Morford and Franck Mauvais-Jarvis \\ Section of Endocrinology and Metabolism, Department of Medicine, Diabetes Discovery Research and Gender Medicine Laboratory, Tulane University \\ Health Sciences Center, School of Medicine, and Southeast Louisiana Veterans Healthcare System Medical Center, New Orleans, Louisiana, USA
}

Correspondence should be addressed to F Mauvais-Jarvis: fmauvais@tulane.edu

\begin{abstract}
One of the most sexually dimorphic aspects of metabolic regulation is the bidirectional modulation of glucose homeostasis by testosterone in male and females. Severe testosterone deficiency predisposes men to type 2 diabetes (T2D), while in contrast, androgen excess predisposes women to hyperglycemia. The role of androgen deficiency and excess in promoting visceral obesity and insulin resistance in men and women respectively is well established. However, although it is established that hyperglycemia requires $\beta$ cell dysfunction to develop, the role of testosterone in $\beta$ cell function is less understood. This review discusses recent evidence that the androgen receptor (AR) is present in male and female $\beta$ cells. In males, testosterone action on AR in $\beta$ cells enhances glucose-stimulated insulin secretion by potentiating the insulinotropic action of glucagonlike peptide-1. In females, excess testosterone action via AR in $\beta$ cells promotes insulin hypersecretion leading to oxidative injury, which in turn predisposes to T2D.
\end{abstract}

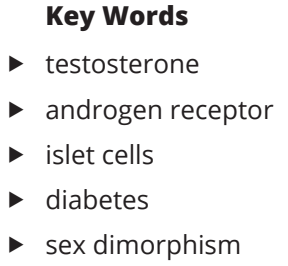

Journal of Endocrinology (2019) 240, R97-R105

\section{Introduction}

The role of sex in metabolic disease is a fundamental issue in endocrinology. Perhaps the most sexually dimorphic aspect of metabolic regulation is the bidirectional modulation of glucose homeostasis and energy balance by the male hormone testosterone in males and females (Navarro et al. 2015, Morford \& Mauvais-Jarvis 2016, Schiffer et al. 2017, Morford et al. 2018). It is well established that testosterone deficiency predisposes men to visceral obesity, metabolic syndrome and T2D (Stellato et al. 2000, Oh et al. 2002, Zitzmann 2009, Navarro et al. 2015). In contrast, testosterone excess predisposes women to obesity, metabolic syndrome and T2D (Oh et al. 2002, Jones et al. 2011, Navarro et al. 2015). Considering that men with testosterone deficiency and women with androgen excess represent a large segment of the population (18\% of men over 70 years old (Araujo et al. 2007) and 5-20\% of women of reproductive age (Azziz et al. 2016), respectively), it is vital to understand the determinants of sex differences in testosterone's effects on metabolic homeostasis (Stellato et al. 2000, Zitzmann 2009, Jones et al. 2011, Schiffer et al. 2017). Although it is established that $\beta$ cell dysfunction is necessary for hyperglycemia to develop, the role of testosterone in $\beta$ cell function and insulin secretion is poorly understood. This review discusses how testosterone acts on the AR in the insulin-producing $\beta$ cells of the pancreas in a sexually dimorphic manner in males and females to promote $\beta$ cell function or dysfunction, respectively.

\section{Testosterone action in $\beta$ cells in men}

Prostate cancer is the most common cancer in men, and androgen deprivation therapy (ADT), the standard 
treatment, promotes severe testosterone deficiency and predisposes patients to metabolic complications (Zitzmann 2009, Faris \& Smith 2010, Navarro et al. 2015). The metabolic effect of testosterone deficiency in promoting visceral obesity and impairing insulin sensitivity in men is well established (Zitzmann 2009, Navarro et al. 2015). In contrast, and surprisingly, the role of testosterone deficiency in predisposing to pancreatic $\beta$ cell dysfunction and therefore insulin deficiency remains ignored. This is particularly surprising, as observational studies have implicated low testosterone levels in both the development of insulin resistance and the pathogenesis of hyperglycemia and diabetes in men, and hyperglycemia requires $\beta$ cell dysfunction to develop. In the Massachusetts Male Aging Study, a population-based prospective study that followed over a 1000 men aged 40-70 years for almost 10 years, the authors reported that low serum testosterone concentrations play a role in the development of T2D (Stellato et al. 2000). In the Rancho Bernardo study, an observational study of the association between endogenous sex hormones and the prospective development of T2D, the authors also concluded that low testosterone concentrations predicted incident T2D in older men (Oh et al. 2002). Consistent with the role of endogenous testosterone in favoring glucose homeostasis in men, two large randomized control trials (RCTs, over 200 subjects) assessing the effect of testosterone therapy on hyperglycemia in hypogonadal patients with T2D revealed a dose-dependent improvement in blood glucose in patients randomized to testosterone (Jones et al. 2011, Hackett et al. 2014). Smaller RCTs have not consistently reported that testosterone therapy improved glycemic control in hypogonadal men with T2D (Grossmann et al. 2015). However, in most of these smaller studies, testosterone deficiency was moderate, diabetes was already well-controlled or the population was heterogeneous, and testosterone deficiency was not the primary driver of T2D development. Overall, systematic reviews and meta-analyses are consistent with a beneficial effect of testosterone therapy in improving glucose homeostasis in men with T2D and primary hypogonadism (reviewed in Harada 2018).

In contrast to patients with hypogonadism and T2D, patients with prostate cancer treated with ADT exhibit primary testosterone deficiency, allowing studies to prospectively assess the direct role of testosterone depletion on diabetes development. The goal of ADT is to suppress testosterone production by bilateral orchidectomy or by using gonadotropin-releasing hormone (GnRH) analogs (Perlmutter \& Lepor 2007).
Alternatively, ADT can also involve blocking the actions of testosterone on the androgen receptor (AR) using AR antagonists. Both treatments, individually or in combination, produce severe cellular testosterone deficiency. Therefore, ADT represents a more rigorous experimental model than hypogonadism to assess the effect of testosterone depletion on the development of hyperglycemia. In a large population-based study of over 70,000 men aged 66 years or older (Medicare enrollees), treated for prostate cancer and without prior diagnosis of diabetes, ADT with GnRH analogs was associated with a $44 \%$ increased risk of incident diabetes $(34 \%$ increased risk for orchidectomy) compared to controls with prostate cancer without ADT (Keating et al. 2006). Similarly, an observational study of over 37,000 men treated for prostate cancer in the Veterans Healthcare Administration showed that ADT with GnRH analogs was associated with a $28 \%$ increased risk of developing diabetes (16\% increased risk for orchidectomy) compared to controls followed for prostate cancer but without ADT (Keating et al. 2010). Thus, ADT and the resulting severe testosterone depletion are instrumental in predisposing to hyperglycemia and diabetes in these men. Importantly, neither insulin resistance nor visceral adiposity can induce hyperglycemia without $\beta$ cell failure to compensate for the insulin resistance (Polonsky 1995, UK Prospective Diabetes Study Group 1995, Weyer et al. 1999, Prentki \& Nolan 2006). This suggests that the hyperglycemia observed in men treated with ADT is at least partially due to $\beta$ cell dysfunction, leading to insulin deficiency. Therefore, the increasing reports of hyperglycemia in patients with ADT suggest that severe testosterone deficiency may predispose to $\beta$ cell failure to compensate for insulin resistance. Consistent with this possibility, one study reported marked hyperglycemia and decreased $\beta$ cell function following ADT among prostate cancer patients (Inaba et al. 2005). In another study performed in obese men with secondary hypogonadism, testosterone therapy improved $\beta$ cell function (HOMA \%B) and glycemic control (Dimitriadis et al. 2018). Taken together, these observations suggest that testosterone deficiency, such as that observed during ADT, predisposes to $\beta$ cell dysfunction and failure in men and that testosterone may improve insulin secretion in these subjects.

To explore this possibility using animal models, we generated mice with selective AR depletion in pancreatic $\beta$ cells ( $\beta$ ARKO) (Navarro et al. 2016). When exposed to a Western diet, male adult $\beta$ ARKO mice developed fasting and fed hypoinsulinemia leading to hyperglycemia. When challenged with IP glucose, male $\beta$ ARKO mice exhibited 
decreased glucose-stimulated insulin secretion (GSIS), leading to an impaired ability to clear glucose. Consistent with the altered GSIS in $\beta$ ARKO mice being $\beta$ cell autonomous, in static incubation, testosterone enhanced GSIS in cultured male islets from human donors and mice, an effect that is not observed in $\beta$ ARKO islets or in human islets treated with an AR antagonist. Further, during islet perifusion, testosterone enhanced the first- and secondphase GSIS in control mouse islets. In contrast, the increased first phase was absent in $\beta$ ARKO islets, and they exhibited aberrant early second phase insulin secretion and lower global insulin secretion. Thus, AR in $\beta$ cells is important to both first- and second-phase GSIS. Together, these observations suggest that testosterone is necessary for normal GSIS in men and that men with androgen deficiency (e.g., those undergoing ADT) develop $\beta$ cell dysfunction that predisposes them to T2D.

In classical androgen-sensitive tissues, AR is a ligandactivated nuclear receptor that regulates gene expression through binding to an androgen response element on the promoter of target genes (Chang et al. 1988, Lubahn et al. 1988, Tilley et al. 1989). Interestingly, in $\beta$ cells, AR exhibits a predominant extranuclear location and remains extranuclear following ligand stimulation. Using an androgen dendrimer conjugate that selectively activates extranuclear AR signaling pathways but remains outside the nucleus, we confirmed that extranuclear AR location is sufficient to enhance GSIS in male mouse and human islets (Navarro et al. 2016).

In $\beta$ cells, GSIS is driven by glucose metabolism through glycolysis and oxidative phosphorylation, which generate ATP (Ashcroft 1980) and trigger intracellular $\left[\mathrm{Ca}^{2+}\right]_{\mathrm{i}}$ influx. Interestingly, testosterone activation of AR in $\beta$ cells potentiates GSIS independently of increases in cellular ATP, membrane depolarization and $\left[\mathrm{Ca}^{2+}\right]_{\mathrm{i}}$ influx. Rather, testosterone enhances GSIS from cultured islets by increasing cAMP accumulation (Navarro et al. 2016). Interestingly, the insulinotropic effect of testosterone alone observed in mouse and human islets is not observed in insulin-secreting INS-1 cells, even though these cells express AR. This observation suggests that the insulinotropic effect of testosterone requires a secreted factor, produced by islet non- $\beta$ cells and acting on $\beta$ cells, to facilitate the effect of testosterone in a paracrine manner. For that reason, we explored the possibility that AR action in $\beta$ cells amplifies GLP-1R signaling to increase cAMP production. We reasoned that because GLP-1 is secreted by $\alpha$ cells (Liu et al. 2011, Marchetti et al. 2012), testosterone would enhance GSIS in cultured islets but not in cultured INS-1 cells (which do not secrete GLP-1). This led to the discovery that the insulinotropic effect of testosterone via AR in islet $\beta$ cells is dependent on activation of the GLP-1 receptor (GLP-1R) by islet-derived GLP-1, as it is abolished in the presence of a GLP-1R antagonist (Navarro et al. 2016). This is consistent with the observation that male $\beta$ ARKO mice exhibit blunted GSIS and glucose intolerance in response to parenteral glucose, which does not activate gut GLP-1 secretion. It also suggests that testosterone amplifies the insulinotropic effect of islet-derived GLP-1 in vivo. Further, in cultured mouse and human islets, testosterone also amplifies the insulinotropic effect of exogenous GLP-1. This paracrine model is consistent with studies showing that in mice, gut GLP-1 acts locally in a paracrine manner through a gut-brain-islet axis to enhance insulin secretion (Smith et al. 2014). Therefore, a model is emerging in which testosterone provides finetuning of insulin secretion in males by enhancing the $\beta$ cell insulinotropic actions of GLP-1 (Fig. 1). Morimoto et al. reported that testosterone stimulates islet insulin synthesis (Morimoto et al. 2001). However, because they used testosterone (which, unlike dihydrotestosterone, is converted into estrogens), the effect on insulin synthesis was likely due to testosterone aromatization to estrogen acting on ERs (Wong et al. 2010).

Surprisingly, male rats with castration-induced testosterone deficiency exhibit a decrease in $\beta$ cell mass due to increased apoptosis and decreased proliferation, but this is not observed in castrated male mice (Harada et al. 2018). Similarly, male $\beta$ ARKO mice show no alteration in $\beta$ cell mass (Navarro et al. 2016).

The evolutionary and biological basis for testosterone stimulation of insulin secretion in males is likely to promote anabolism, since both testosterone and insulin are anabolic hormones. Testosterone secretion is pulsatile and is acutely stimulated by mating and dominance (Archer 2006), both of which require optimal energy stores. Likely, testosterone pulses have enduring actions to sensitize $\beta$ cells by raising the basal level of cAMP. Therefore, the integration of androgenic and metabolic signals could be an evolutionary strategy to enhance muscle anabolism and glycogen storage in males when food is available. Thus, pulsatile testosterone secretion could constitute another layer of regulation that affects $\beta$ cell function (Wortham \& Sander 2016).

The AR is also important for male $\beta$ cell health. The AR-dependent gene network was investigated in $\beta$ cells following a high-throughput whole transcriptome sequencing (RNA-Seq) in islets from male $\beta$ ARKO and control mice (Xu et al. 2017). AR-deficient islets exhibited altered expression of 214 genes (DEGs) 


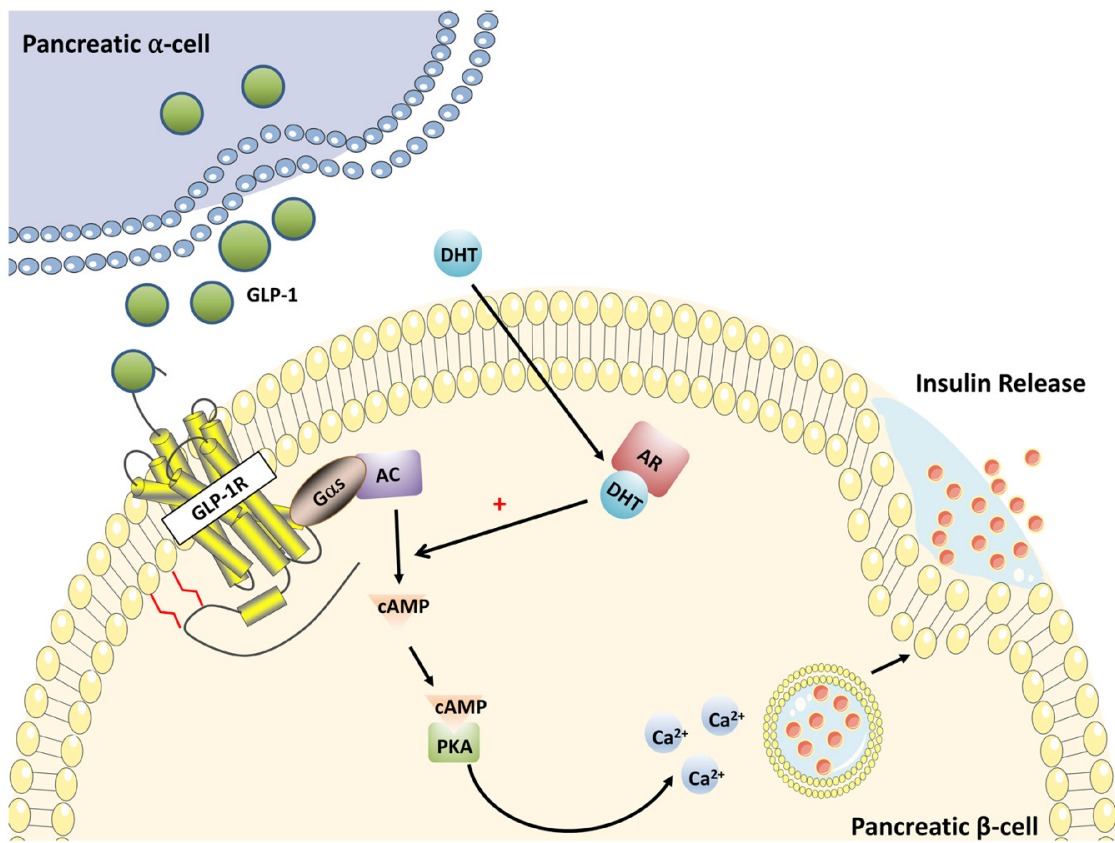

\section{Figure 1}

Mechanism of testosterone insulinotropic action in $\beta$ cell. Testosterone action on an extranuclear AR in $\beta$ cell amplifies the insulinotropic action of islet-derived GLP-1 by increasing CAMP production and PKA activation. with a fold change $>2$. A third of these genes code for proteins involved in inflammation and cellular stress, demonstrating that islets lacking AR are adapting to injury. These include Fgf21 (Wente et al. 2006), Lcn2 (Chang et al. 2013), osteoprotegerin (Maruyama et al. 2006, Reid \& Holen 2009), chemokine ligands 5 and 10 (Schulthess et al. 2009, Nunemaker et al. 2014), several interferon-gamma-induced guanylate-binding proteins (Kim et al. 2016), intra-islet proinflammatory cytokines and associated receptors like interleukin$1 \beta$, the interleukin 22 receptor- $\alpha 1$ (Shioya et al. 2008), the interleukin-1 receptor antagonist (Dayer-Metroz et al. 1989) and interleukin-10. A fifth of dysregulated genes are involved in $\beta$ cell function. These include genes coding for G-protein-coupled receptors such as Gpr161 (Bachmann et al. 2016), Gpr126 (Mogha et al. 2013), Gpr26 (Zhang et al. 2011), ion channels altering membrane polarization like the potassium inwardlyrectifying channel, subfamily J, member 5 (kcnj5), the potassium voltage-gated channel, subfamily Q, member 1 (kcnq1) (33) and trpc4 (Islam 2011). Dysregulated genes also code for proteins involved in $\beta$ cell exocytosis machinery such as synaptotagmin-10 (Cao et al. 2011), rabphilin 3a (Arribas et al. 1997) and enzymes involved in glucose metabolism, hexokinase 2, hexokinase domain containing 1 (Ludvik et al. 2016) and glucokinase-binding protein 6-phosphofructo-2kinase/fructose-2,6-biphosphatase 3 (Arden et al. 2008).
Taken together, the studies described above demonstrate that testosterone action via AR is necessary for $\beta$ cell health and normal GSIS in male mice, and probably also in men. Therefore, we propose that moderate androgen deficiency in men promotes adiposity and insulin resistance, but with moderate $\beta$ cell dysfunction, and the incidence of T2D is mild. However, during severe androgen deficiency resulting from ADT, men display a more profound $\beta$ cell dysfunction that further accelerates the progression toward T2D (Fig. 2).

These findings have clinical and therapeutic implications. Selective androgen receptor modulators (SARMs) are in development to provide androgen therapy for age-related frailty with androgenic anabolic activity in muscle and bone, but without androgenic stimulation of the prostate (Mohler et al. 2009). Obviously, the design of SARMs with AR agonistic action in $\beta$ cells represents a therapeutic avenue to prevent androgen deficiencyrelated diabetes in men.

Surprisingly, despite AR protein expression in islets and $\beta$ cells, and functional studies described earlier demonstrating the importance of AR in GSIS in vivo, genome wide transcriptome analyses of mouse islets have failed to detect appreciable levels of AR mRNA (Xu et al. 2017). This discrepancy is likely related to tissue-specific AR mRNA instability (Krongrad et al. 1991, Yeap et al. 1999, 2004) or the high glucose-induced AR mRNA degradation under islet culture conditions (Harada et al. 2018). 


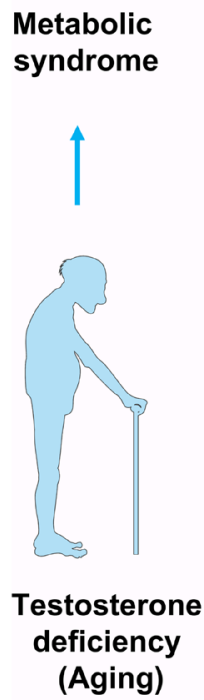

Testosterone action in $\beta$ cells in women

The association between testosterone excess and the development of hyperglycemia in women has been known for nearly a century (Achard \& Thiers 1921). Polycystic ovarian syndrome (PCOS), the main cause of testosterone excess, predisposes women to T2D (Ehrmann et al. 1999, Legro et al. 1999, Rubin et al. 2017). In syndromes of extreme insulin resistance, and in obese women with PCOS, insulin resistance is the driver of the ovarian production of androgens (Spiegelman \& Flier 1996); however, in the most common form of PCOS, androgen excess is instrumental in promoting hyperglycemia. As discussed in the previous section for males, the development of hyperglycemia in women with PCOS suggests that androgen excess promotes $\beta$ cell dysfunction in women. In fact, clinical evidence suggests that this is the case. First, women with hyperandrogenemia exhibit either higher basal insulin secretion and decreased post-prandial insulin secretion (O'Meara et al. 1993) or exaggerated acute insulin response to glucose (Dunaif $\&$ Finegood 1996). These alterations in $\beta$ cell function are not explained by insulin resistance. Rather, they are closely associated with testosterone levels (Holte et al. 1994). Finally, there is a robust relationship between $\beta$ cell dysfunction and testosterone concentrations in these women (Goodarzi et al. 2005, Zhang et al. 2018). Since the AR is expressed in $\beta$ cells in females, this raises the possibility that excess testosterone produces insulin hypersecretion and $\beta$ cell dysfunction. Consistent with this possibility, Mishra et al. observed that female rats exposed to androgen excess using dihydrotestosterone

\section{Diabetes}
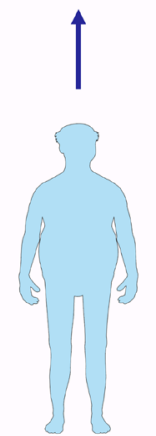

Severe testosterone deficiency (ADT)

\section{Figure 2}

Mechanism of diabetes in men with androgen deficiency. Moderate androgen deficiency during aging predisposes men to increased adiposity and insulin resistance leading to metabolic syndrome. During severe androgen deficiency such as androgen depletion therapy (ADT), the additional $\beta$ cell dysfunction predisposes to diabetes.

(DHT) exhibit hyperinsulinemia through an increase in the transcription of the insulin gene in pancreatic $\beta$ cells (Mishra et al. 2018). Testosterone excess may predispose women to T2D via chronic AR activation in pancreatic islet $\beta$ cells, producing insulin hypersecretion and secondary $\beta$ cell failure. To explore this hypothesis, we generated female mice with testosterone excess and conditional AR deletion in $\beta$ cells ( $\beta$ ARKO) (Navarro et al. 2018). Under conditions of Western diet feeding, control mice with chronic testosterone excess developed abnormalities characteristic of early T2D. They displayed fasting and fed hyperinsulinemia associated with exaggerated GSIS and insulin resistance. Accordingly, these mice developed compensatory $\beta$ cell hyperplasia with increased $\beta$ cell mass. However, they also developed secondary $\beta$ cell failure due to a failed attempt at compensation for insulin resistance, leading to hyperglycemia in the fasting and fed state and during a glucose challenge. In contrast, in female $\beta$ ARKO mice, testosterone did not produce fasting hyperinsulinemia. These mice remained normoglycemic in the fasting and fed states and during a glucose challenge, demonstrating that, during testosterone excess, AR activation in $\beta$ cells is necessary for the development of hyperglycemia in female mice. Although testosterone activation of AR in neurons produced peripheral insulin resistance in these mice, evidence supports the role of AR activation in $\beta$ cells in the development of $\beta$ cell failure. First, acute testosterone exposure produces insulin hypersecretion in an AR-dependent manner in cultured female mouse and human islets incubated in high glucose. In addition, testosterone enhanced both first- and second-phase insulin secretion during female mouse islet 


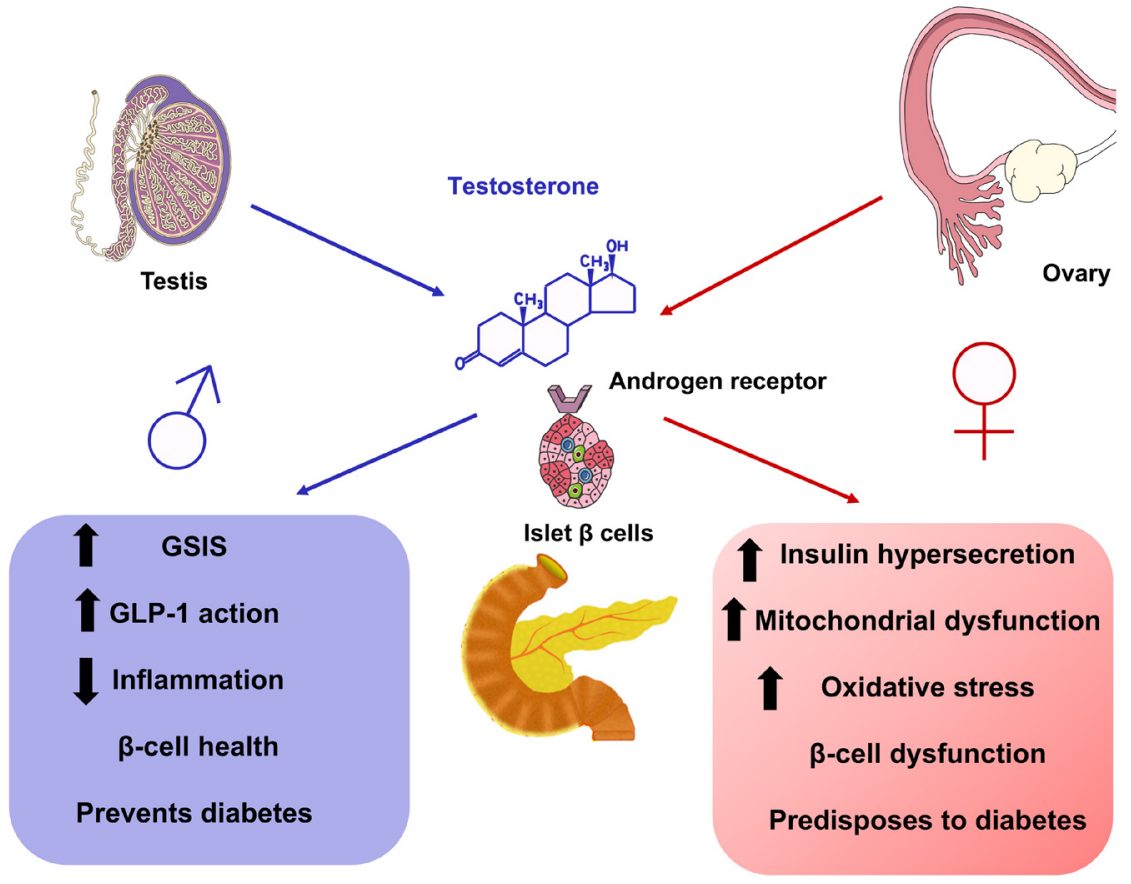

\section{Figure 3}

Summary of the bidirectional modulation of $\beta$ cell function in males and females. In males, testosterone action in $\beta$ cells increases GSIS by enhancing GLP-1 insulinotropic action, prevents inflammation and promotes $\beta$ cell health. In females, testosterone excess in $\beta$ cells promotes insulin hypersecretion, mitochondrial dysfunction, oxidative stress and predisposes to $\beta$ cell dysfunction and failure. perifusion. Second, testosterone enhances mitochondrial respiration and oxygen consumption in female mouse cultured islets, and accordingly, chronic testosterone excess in vivo produces islet oxidative injury via AR in $\beta$ cells. Female mice exposed to chronic testosterone excess become more susceptible to additional islet oxidative stress induced by either a Western diet or streptozotocin, in a manner dependent on AR in $\beta$ cells (Navarro et al. 2018). Further, female rats exposed to DHT excess exhibit significant mitochondrial dysfunction with decreased mitochondrial DNA copy number, increased reactive oxygen production and downregulation of mitochondrial biogenesis (Mishra et al. 2018). Together, these studies suggest that, in the presence of prior or additional islet metabolic stress, the deleterious effect of chronic AR activation by testosterone causes $\beta$ cell hyperfunction, oxidative stress and mitochondrial dysfunction, which predisposes to secondary $\beta$ cell demise in female mice. Additionally, hyperglycemia-induced inflammation further deteriorates $\beta$ cell function in women with PCOS (Malin et al. 2015).

In addition to adult androgen excess, developmental androgen excess in female mammal fetuses programs female $\beta$ cells in utero via AR (Mauvais-Jarvis 2016). The developmental effect of testosterone alters insulin secretion in adult female offspring, leading to basal hyperinsulinemia (independent from insulin resistance) but reduced insulin secretion in response to $\beta$ cell dysfunction, as observed in adult females with androgen excess.

\section{Conclusion and future perspectives}

The studies reviewed here demonstrate that testosterone acts in $\beta$ cells to differentially modulate $\beta$ cell function in males and females. In males, physiological concentrations of testosterone enhance GSIS in a physiological manner, and loss of AR action in $\beta$ cells produces insulin deficiency, which predisposes to diabetes. In contrast, in females, increasing circulating testosterone concentrations to levels observed in males activates AR in $\beta$ cells to enhance GSIS in a non-physiological manner, leading to mitochondrial dysfunction, oxidative stress and ultimately resulting in $\beta$ cell dysfunction that predisposes to diabetes. Further studies are needed to unravel the molecular determinants of this bidirectional modulation of $\beta$ cell function in male and females. The actions of testosterone in male and female $\beta$ cells are summarized in Fig. 3.

\section{Declaration of interest}

The authors declare that there is no conflict of interest that could be perceived as prejudicing the impartiality of this review.

\section{Funding}

This work was supported by grants from the National Institutes of Health (R01 DK074970, and DK107444), a Department of Veterans Affairs Merit Review Award (\#BX003725) and the Price-Goldsmith Endowed Chair at Tulane University School of Medicine. 


\section{References}

Achard C \& Thiers J 1921 Le virilisme pilaire et son association a l'insuffisance glycolytique (diabete des femmes a barbe). Bulletin de l'Académie Nationale de Médecine 86 51-55.

Araujo AB, Esche GR, Kupelian V, O'Donnell AB, Travison TG, Williams RE, Clark RV \& Mckinlay JB 2007 Prevalence of symptomatic androgen deficiency in men. Journal of Clinical Endocrinology and Metabolism 92 4241-4247. (https://doi.org/10.1210/jc.2007-1245)

Archer J 2006 Testosterone and human aggression: an evaluation of the challenge hypothesis. Neuroscience and Biobehavioral Reviews 30 319-345. (https://doi.org/10.1016/j.neubiorev.2004.12.007)

Arden C, Hampson LJ, Huang GC, Shaw JA, Aldibbiat A, Holliman G, Manas D, Khan S, Lange AJ \& Agius L 2008 A role for PFK-2/FBPase-2, as distinct from fructose 2,6-bisphosphate, in regulation of insulin secretion in pancreatic beta cells. Biochemical Journal 411 41-51. (https://doi.org/10.1042/BJ20070962)

Arribas M, Regazzi R, Garcia E, Wollheim CB \& De Camilli P 1997 The stimulatory effect of rabphilin $3 \mathrm{a}$ on regulated exocytosis from insulin-secreting cells does not require an association-dissociation cycle with membranes mediated by Rab 3. European Journal of Cell Biology 74 209-216.

Ashcroft SJ 1980 Glucoreceptor mechanisms and the control of insulin release and biosynthesis. Diabetologia 18 5-15. (https://doi. org/10.1007/BF01228295)

Azziz R, Carmina E, Chen Z, Dunaif A, Laven JS, Legro RS, Lizneva D, Natterson-Horowtiz B, Teede HJ \& Yildiz BO 2016 Polycystic ovary syndrome. Nature Reviews Disease Primers 2 16057. (https://doi. org/10.1038/nrdp.2016.57)

Bachmann VA, Mayrhofer JE, Ilouz R, Tschaikner P, Raffeiner P, Rock R, Courcelles M, Apelt F, Lu TW, Baillie GS, et al. 2016 Gpr161 anchoring of PKA consolidates GPCR and cAMP signaling. PNAS 113 7786-7791. (https://doi.org/10.1073/pnas.1608061113)

Cao P, Maximov A \& Sudhof TC 2011 Activity-dependent IGF-1 exocytosis is controlled by the $\mathrm{Ca}(2+)$-sensor synaptotagmin-10. Cell 145 300-311. (https://doi.org/10.1016/j.cell.2011.03.034)

Chang CS, Kokontis J \& Liao ST 1988 Molecular cloning of human and rat complementary DNA encoding androgen receptors. Science $\mathbf{2 4 0}$ 324-326. (https://doi.org/10.1126/science.3353726)

Chang SY, Kim DB, Ko SH, Jo YH \& Kim MJ 2013 Induction mechanism of lipocalin-2 expression by co-stimulation with interleukin-1beta and interferon-gamma in RINm5F beta cells. Biochemical and Biophysical Research Communications 434 577-583. (https://doi.org/10.1016/j. bbrc.2013.03.117)

Dayer-Metroz MD, Wollheim CB, Seckinger P \& Dayer JM 1989 A natural interleukin 1 (IL-1) inhibitor counteracts the inhibitory effect of IL-1 on insulin production in cultured rat pancreatic islets. Journal of Autoimmunity 2 163-171. (https://doi.org/10.1016/08968411(89)90152-2)

Dimitriadis GK, Randeva HS, Aftab S, Ali A, Hattersley JG, Pandey S, Grammatopoulos DK, Valsamakis G, Mastorakos G, Jones TH, et al. 2018 Metabolic phenotype of male obesity-related secondary hypogonadism pre-replacement and post-replacement therapy with intra-muscular testosterone undecanoate therapy. Endocrine $\mathbf{6 0}$ 175-184. (https://doi.org/10.1007/s12020-017-1516-x)

Dunaif A \& Finegood DT 1996 Beta cell dysfunction independent of obesity and glucose intolerance in the polycystic ovary syndrome. Journal of Clinical Endocrinology and Metabolism 81 942-947. (https:// doi.org/10.1210/jcem.81.3.8772555)

Ehrmann DA, Barnes RB, Rosenfield RL, Cavaghan MK \& Imperial J 1999 Prevalence of impaired glucose tolerance and diabetes in women with polycystic ovary syndrome. Diabetes Care 22 141-146. (https://doi. org/10.2337/diacare.22.1.141)
Faris JE \& Smith MR 2010 Metabolic sequelae associated with androgen deprivation therapy for prostate cancer. Current Opinion in Endocrinology, Diabetes and Obesity 17 240-246. (https://doi. org/10.1097/MED.0b013e3283391fd1)

Goodarzi MO, Erickson S, Port SC, Jennrich RI \& Korenman SG 2005 beta-Cell function: a key pathological determinant in polycystic ovary syndrome. Journal of Clinical Endocrinology and Metabolism 90 310-315. (https://doi.org/10.1210/jc.2004-1006)

Grossmann M, Hoermann R, Wittert G \& Yeap BB 2015 Effects of testosterone treatment on glucose metabolism and symptoms in men with type 2 diabetes and the metabolic syndrome: a systematic review and meta-analysis of randomized controlled clinical trials. Clinical Endocrinology 83 344-351. (https://doi.org/10.1111/ cen.12664)

Hackett G, Cole N, Bhartia M, Kennedy D, Raju J \& Wilkinson P 2014 Testosterone replacement therapy improves metabolic parameters in hypogonadal men with type 2 diabetes but not in men with coexisting depression: the BLAST study. Journal of Sexual Medicine $\mathbf{1 1}$ 840-856. (https://doi.org/10.1111/jsm.12404)

Harada N 2018 Role of androgens in energy metabolism affecting on body composition, metabolic syndrome, type 2 diabetes, cardiovascular disease, and longevity: lessons from a meta-analysis and rodent studies. Bioscience, Biotechnology and Biochemistry $\mathbf{8 2}$ 1667-1682. (https://doi.org/10.1080/09168451.2018.1490172)

Harada N, Yoda Y, Yotsumoto Y, Masuda T, Takahashi Y, Katsuki T, Kai K, Shiraki N, Inui H \& Yamaji R 2018 Androgen signaling expands beta cell mass in male rats and beta cell androgen receptor is degraded under high-glucose conditions. American Journal of Physiology: Endocrinology and Metabolism 314 E274-E286. (https://doi. org/10.1152/ajpendo.00211.2017)

Holte J, Bergh T, Berne C, Berglund L \& Lithell H 1994 Enhanced early insulin response to glucose in relation to insulin resistance in women with polycystic ovary syndrome and normal glucose tolerance. Journal of Clinical Endocrinology and Metabolism 78 1052-1058. (https://doi. org/10.1210/jcem.78.5.8175959)

Inaba M, Otani Y, Nishimura K, Takaha N, Okuyama A, Koga M, Azuma J, Kawase I \& Kasayama S 2005 Marked hyperglycemia after androgendeprivation therapy for prostate cancer and usefulness of pioglitazone for its treatment. Metabolism $\mathbf{5 4} 55-59$. (https://doi.org/10.1016/j. metabol.2004.07.010)

Islam MS 2011 TRP channels of islets. Advances in Experimental Medicine and Biology 704 811-830.

Jones TH, Arver S, Behre HM, Buvat J, Meuleman E, Moncada I, Morales AM, Volterrani M, Yellowlees A, Howell JD, et al. 2011 Testosterone replacement in hypogonadal men with type 2 diabetes and/or metabolic syndrome (the TIMES2 study). Diabetes Care 34 828-837. (https://doi.org/10.2337/dc10-1233)

Keating NL, O'Malley AJ \& Smith MR 2006 Diabetes and cardiovascular disease during androgen deprivation therapy for prostate cancer. Journal of Clinical Oncology 24 4448-4456. (https://doi.org/10.1200/ JCO.2006.06.2497)

Keating NL, O'Malley AJ, Freedland SJ \& Smith MR 2010 Diabetes and cardiovascular disease during androgen deprivation therapy: observational study of veterans with prostate cancer. Journal of the National Cancer Institute 102 39-46. (https://doi.org/10.1093/jnci/ djp404)

Kim BH, Chee JD, Bradfield CJ, Park ES, Kumar P \& Macmicking JD 2016 Interferon-induced guanylate-binding proteins in inflammasome activation and host defense. Nature Immunology 17 481-489. (https:// doi.org/10.1038/ni.3440)

Krongrad A, Wilson CM, Wilson JD, Allman DR \& Mcphaul MJ 1991 Androgen increases androgen receptor protein while decreasing receptor mRNA in LNCaP cells. Molecular and Cellular Endocrinology $\mathbf{7 6}$ 79-88. (https://doi.org/10.1016/0303-7207(91)90262-Q) https://joe.bioscientifica.com https://doi.org/10.1530/JOE-18-0573 (c) 2019 Society for Endocrinology Published by Bioscientifica Ltd. Printed in Great Britain 
Legro RS, Kunselman AR, Dodson WC \& Dunaif A 1999 Prevalence and predictors of risk for type 2 diabetes mellitus and impaired glucose tolerance in polycystic ovary syndrome: a prospective, controlled study in 254 affected women. Journal of Clinical Endocrinology and Metabolism 84 165-169.

Liu Z, Stanojevic V, Avadhani S, Yano T \& Habener JF 2011 Stromal cell-derived factor-1 (SDF-1)/chemokine (C-X-C motif) receptor 4 (CXCR4) axis activation induces intra-islet glucagon-like peptide-1 (GLP-1) production and enhances beta cell survival. Diabetologia 54 2067-2076. (https://doi.org/10.1007/s00125-011-2181-x)

Lubahn DB, Joseph DR, Sullivan PM, Willard HF, French FS \& Wilson EM 1988 Cloning of human androgen receptor complementary DNA and localization to the X chromosome. Science 240 327-330. (https://doi. org/10.1126/science.3353727)

Ludvik AE, Pusec CM, Priyadarshini M, Angueira AR, Guo C, Lo A, Hershenhouse KS, Yang GY, Ding X, Reddy TE, et al. 2016 HKDC1 is a novel hexokinase involved in whole-body glucose use. Endocrinology 157 3452-3461. (https://doi.org/10.1210/en.2016-1288)

Malin SK, Kirwan JP, Sia CL \& Gonzalez F 2015 Pancreatic beta cell dysfunction in polycystic ovary syndrome: role of hyperglycemiainduced nuclear factor-kappaB activation and systemic inflammation. American Journal of Physiology: Endocrinology and Metabolism 308 E770-E777. (https://doi.org/10.1152/ajpendo.00510.2014)

Marchetti P, Lupi R, Bugliani M, Kirkpatrick CL, Sebastiani G, Grieco FA, Del Guerra S, D’Aleo V, Piro S, Marselli L, et al. 2012 A local glucagonlike peptide 1 (GLP-1) system in human pancreatic islets. Diabetologia 55 3262-3272. (https://doi.org/10.1007/s00125-012-2716-9)

Maruyama K, Takada Y, Ray N, Kishimoto Y, Penninger JM, Yasuda H \& Matsuo K 2006 Receptor activator of NF-kappa B ligand and osteoprotegerin regulate proinflammatory cytokine production in mice. Journal of Immunology 177 3799-3805. (https://doi.org/10.4049/ jimmunol.177.6.3799)

Mauvais-Jarvis F 2016 Role of sex steroids in beta cell function, growth, and survival. Trends in Endocrinology and Metabolism 27 844-855. (https://doi.org/10.1016/j.tem.2016.08.008)

Mishra JS, More AS \& Kumar S 2018 Elevated androgen levels induce hyperinsulinemia through increase in Ins1 transcription in pancreatic beta cells in female rats. Biology of Reproduction 98 520-531. (https:// doi.org/10.1093/biolre/ioy017)

Mogha A, Benesh AE, Patra C, Engel FB, Schoneberg T, Liebscher I \& Monk KR 2013 Gpr126 functions in Schwann cells to control differentiation and myelination via G-protein activation. Journal of Neuroscience 33 17976-17985. (https://doi.org/10.1523/ JNEUROSCI.1809-13.2013)

Mohler ML, Bohl CE, Jones A, Coss CC, Narayanan R, He Y, Hwang DJ, Dalton JT \& Miller DD 2009 Nonsteroidal selective androgen receptor modulators (SARMs): dissociating the anabolic and androgenic activities of the androgen receptor for therapeutic benefit. Journal of Medicinal Chemistry 52 3597-3617. (https://doi.org/10.1021/ jm900280m)

Morford J \& Mauvais-Jarvis F 2016 Sex differences in the effects of androgens acting in the central nervous system on metabolism. Dialogues in Clinical Neuroscience 18 415-424.

Morford JJ, Wu S \& Mauvais-Jarvis F 2018 The impact of androgen actions in neurons on metabolic health and disease. Molecular and Cellular Endocrinology 465 92-102. (https://doi.org/10.1016/j. mce.2017.09.001)

Morimoto S, Cerbon MA, Alvarez-Alvarez A, Romero-Navarro G \& Diaz-Sanchez V 2001 Insulin gene expression pattern in rat pancreas during the estrous cycle. Life Science 68 2979-2985. (https://doi. org/10.1016/S0024-3205(01)01100-6)

Navarro G, Allard C, Xu W \& Mauvais-Jarvis F 2015 The role of androgens in metabolism, obesity, and diabetes in males and females. Obesity 23 713-719. (https://doi.org/10.1002/oby.21033)

Navarro G, Xu W, Jacobson DA, Wicksteed B, Allard C, Zhang G, De Gendt K, Kim SH, Wu H, Zhang H, et al. 2016 Extranuclear actions of the androgen receptor enhance glucose-stimulated insulin secretion in the male. Cell Metabolism 23 837-851. (https://doi.org/10.1016/j. cmet.2016.03.015)

Navarro G, Allard C, Morford JJ, Xu W, Liu S, Molinas AJ, Butcher SM, Fine NHF, Blandino-Rosano M, Sure VN, et al. 2018 Androgen excess in pancreatic beta cells and neurons predisposes female mice to type 2 diabetes. JCI Insight 3 98607. (https://doi.org/10.1172/jci. insight.98607)

Nunemaker CS, Chung HG, Verrilli GM, Corbin KL, Upadhye A \& Sharma PR 2014 Increased serum CXCL1 and CXCL5 are linked to obesity, hyperglycemia, and impaired islet function. Journal of Endocrinology 222 267-276. (https://doi.org/10.1530/JOE-14-0126)

Oh JY, Barrett-Connor E, Wedick NM \& Wingard DL 2002 Endogenous sex hormones and the development of type 2 diabetes in older men and women: the Rancho Bernardo study. Diabetes Care 25 55-60. (https://doi.org/10.2337/diacare.25.1.55)

O'Meara NM, Blackman JD, Ehrmann DA, Barnes RB, Jaspan JB, Rosenfield RL \& Polonsky KS 1993 Defects in beta cell function in functional ovarian hyperandrogenism. Journal of Clinical Endocrinology and Metabolism 76 1241-1247. (https://doi.org/10.1210/ jcem.76.5.8496316)

Perlmutter MA \& Lepor H 2007 Androgen deprivation therapy in the treatment of advanced prostate cancer. Reviews in Urology 9 (Supplement 1) S3-S8.

Polonsky KS 1995 Lilly Lecture 1994. The beta cell in diabetes: from molecular genetics to clinical research. Diabetes 44 705-717. (https:// doi.org/10.2337/diab.44.6.705)

Prentki M \& Nolan CJ 2006 Islet beta cell failure in type 2 diabetes. Journal of Clinical Investigation 116 1802-1812. (https://doi. org/10.1172/JCI29103)

Reid P \& Holen I 2009 Pathophysiological roles of osteoprotegerin (OPG). European Journal of Cell Biology 88 1-17. (https://doi.org/10.1016/j. ejcb.2008.06.004)

Rubin KH, Glintborg D, Nybo M, Abrahamsen B \& Andersen M 2017 Development and risk factors of type 2 diabetes in a nationwide population of women with polycystic ovary syndrome. Journal of Clinical Endocrinology and Metabolism 102 3848-3857. (https://doi. org/10.1210/jc.2017-01354)

Schiffer L, Kempegowda P, Arlt W \& O'Reilly MW 2017 MECHANISMS IN ENDOCRINOLOGY: The sexually dimorphic role of androgens in human metabolic disease. European Journal of Endocrinology 177 R125-R143. (https://doi.org/10.1530/EJE-17-0124)

Schulthess FT, Paroni F, Sauter NS, Shu L, Ribaux P, Haataja L, Strieter RM, Oberholzer J, King CC \& Maedler K 2009 CXCL10 impairs beta cell function and viability in diabetes through TLR4 signaling. Cell Metabolism 9 125-139. (https://doi.org/10.1016/j. cmet.2009.01.003)

Shioya M, Andoh A, Kakinoki S, Nishida A \& Fujiyama Y 2008 Interleukin 22 receptor 1 expression in pancreas islets. Pancreas 36 197-199. (https://doi.org/10.1097/MPA.0b013e3181594258)

Smith EP, An Z, Wagner C, Lewis AG, Cohen EB, Li B, Mahbod P, Sandoval D, Perez-Tilve D, Tamarina N, et al. 2014 The role of beta cell glucagon-like peptide-1 signaling in glucose regulation and response to diabetes drugs. Cell Metabolism 19 1050-1057. (https:// doi.org/10.1016/j.cmet.2014.04.005)

Spiegelman BM \& Flier JS 1996 Adipogenesis and obesity: rounding out the big picture. Cell 87 377-389. (https://doi.org/10.1016/S00928674(00)81359-8)

Stellato RK, Feldman HA, Hamdy O, Horton ES \& Mckinlay JB 2000 Testosterone, sex hormone-binding globulin, and the development of type 2 diabetes in middle-aged men: prospective results from the Massachusetts male aging study. Diabetes Care 23 490-494. (https:// doi.org/10.2337/diacare.23.4.490)

Tilley WD, Marcelli M, Wilson JD \& Mcphaul MJ 1989 Characterization and expression of a cDNA encoding the human androgen receptor. PNAS 86 327-331. (https://doi.org/10.1073/pnas.86.1.327) https://joe.bioscientifica.com

https://doi.org/10.1530/JOE-18-0573 (c) 2019 Society for Endocrinology Published by Bioscientifica Ltd. Printed in Great Britain 
UK Prospective Diabetes Study Group 1995 U.K. prospective diabetes study 16. Overview of 6 years' therapy of type II diabetes: a progressive disease. U.K. Prospective Diabetes Study Group. Diabetes 44 1249-1258. (https://doi.org/10.2337/diab.44.11.1249)

Wente W, Efanov AM, Brenner M, Kharitonenkov A, Koster A, Sandusky GE, Sewing S, Treinies I, Zitzer H \& Gromada J 2006 Fibroblast growth factor- 21 improves pancreatic beta cell function and survival by activation of extracellular signal-regulated kinase $1 / 2$ and Akt signaling pathways. Diabetes 55 2470-2478. (https://doi. org/10.2337/db05-1435)

Weyer C, Bogardus C, Mott DM \& Pratley RE 1999 The natural history of insulin secretory dysfunction and insulin resistance in the pathogenesis of type 2 diabetes mellitus. Journal of Clinical Investigation 104 787-794. (https://doi.org/10.1172/JCI7231)

Wong WP, Tiano JP, Liu S, Hewitt SC, Le May C, Dalle S, Katzenellenbogen JA, Katzenellenbogen BS, Korach KS \& MauvaisJarvis F 2010 Extranuclear estrogen receptor-alpha stimulates NeuroD1 binding to the insulin promoter and favors insulin synthesis. PNAS $\mathbf{1 0 7}$ 13057-13062. (https://doi.org/10.1073/pnas.0914501107)

Wortham M \& Sander M 2016 High T gives beta cells a boost. Cell Metabolism 23 761-763. (https://doi.org/10.1016/j.cmet.2016.04.015)

Xu W, Niu T, Xu B, Navarro G, Schipma MJ \& Mauvais-Jarvis F 2017 Androgen receptor-deficient islet beta cells exhibit alteration in genetic markers of insulin secretion and inflammation. A transcriptome analysis in the male mouse. Journal of Diabetes and its Complications 31 787-795. (https://doi.org/10.1016/j. jdiacomp.2017.03.002)

Yeap BB, Krueger RG \& Leedman PJ 1999 Differential posttranscriptional regulation of androgen receptor gene expression by androgen in prostate and breast cancer cells. Endocrinology 140 3282-3291. (https://doi.org/10.1210/endo.140.7.6769)

Yeap BB, Wilce JA \& Leedman PJ 2004 The androgen receptor mRNA. Bioessays 26 672-682. (https://doi.org/10.1002/bies.20051)

Zhang LL, Wang JJ, Liu Y, Lu XB, Kuang Y, Wan YH, Chen Y, Yan HM, Fei J \& Wang ZG 2011 GPR26-deficient mice display increased anxiety- and depression-like behaviors accompanied by reduced phosphorylated cyclic AMP responsive element-binding protein level in central amygdala. Neuroscience 196 203-214. (https://doi. org/10.1016/j.neuroscience.2011.08.069)

Zhang B, Wang J, Shen S, Liu J, Sun J, Gu T, Ye X, Zhu D \& Bi Y 2018 Association of androgen excess with glucose intolerance in women with polycystic ovary syndrome. BioMed Research International 2018 6869705. (https://doi.org/10.1155/2018/6869705)

Zitzmann M 2009 Testosterone deficiency, insulin resistance and the metabolic syndrome. Nature Reviews Endocrinology 5 673-681. (https:// doi.org/10.1038/nrendo.2009.212)

Received in final form 27 November 2018

Accepted 24 December 2018

Accepted Preprint published online 2 January 2019 https://joe.bioscientifica.com

https://doi.org/10.1530/JOE-18-0573
(C) 2019 Society for Endocrinology Published by Bioscientifica Ltd. 